\title{
From Industrialization to Urbanization: The Social Consequences of Changing Fiscal Incentives on Local Governments’ Behavior ${ }^{1}$
}

\author{
James Kai-sing KUNG (sojk@ust.hk) \\ Hong Kong University of Science \& Technology \\ Chenggang XU (gxu@hku.hk) \\ University of Hong Kong
}

Feizhou ZHOU

Peking University

March 2009

Forthcoming in Joseph E. Stiglitz (ed.), Institutional Design for China's Evolving Market Economy.

\footnotetext{
${ }^{1}$ Comments from the IPD China Task Force Manchester Workshop, particularly Joseph Stiglitz, Christine Wong and an anonymous referee, are gratefully acknowledged. We thank Xiulin Sun for helpful research assistance.
} 


\section{Introduction}

China has experienced sustained economic growth of more than 9\% per annum during 1978-2005—a record that surpassed even the miraculous growth rate of the group of four East Asian economies in the 1970s and 80s. What is even more striking is that this sustained growth was, at least until the late 1990s, achieved in large part under predominantly public ownership with the township-and-village enterprises (hereafter TVEs) being the most notable organizational form under the purview of subnational governments. ${ }^{2}$ Regional decentralization, which drives regional competition or specifically “yardstick jurisdictional competition” and regional experiments, has been a principal force underpinning China's unorthodox growth experience (Xu, 2009). Specifically, “yardstick jurisdictional competition” refers to a process that relies on regions facing similar external economic environment to compete with one another on a (more or less) equal footing in a decentralized and non-specialized environment (Maskin, Qian and $\mathrm{Xu}, 2000$ ). At an earlier stage, and as part and parcel of China's reform strategy based upon regional decentralization, the central state adopted the specific strategy of fiscal decentralization in the early 1980s. By assigning residual tax claiming rights to various levels of local governments, this fiscal measure empowered them with positive inducements to promote local economic growth (Oi, 1999). Thus, despite the notable absence of private property rights, these regional decentralization-based reforms led to sustained local economic growth.

In this chapter we investigate how the powerful incentive of fiscal stimulus has induced local governments to switch their development focus from industrializing their jurisdictions to urbanizing them, as articulated in the eventual demise of TVEs after its phenomenal rise, followed by the boom (and recently bust) of a real estate sector in recent years. Determined to enhance "state capacity", the central state attenuated the claims of local governments over tax revenues generated by their nonstate, non-private enterprises; the 1994 fiscal recentralization reduced the share of local governments' entitlement to an important tax source, namely value-added or transaction tax by a substantial 75\%. In order to compensate local governments for the losses thus resulted, local governments were assigned greater control rights over

\footnotetext{
${ }^{2}$ While the term is usually referred to the provincial level and below, in this paper we are mostly concerned with the economic behavior of lower-level government authorities spanning the municipal and township authorities.
} 
revenues generated, initially, by local state firms, followed by land sales; to the extent that the overall regional decentralization strategy which underpinned economic growth has not been weakened by this particular fiscal recentralization measure. In fact, the incentives of local governments in promoting rural industrialization had remained unchanged up to this stage of the reform. It was only until the central state further reduced the local governments' share in enterprise profit tax-also by a substantial 60\% in 2002 — did the latter find it no longer profitable to continue to run industrial enterprises that were barely profitable. It was then that many local governments began to pursue the alternative strategy of “urbanization”.

Why are local governments interested in urbanizing their localities, more importantly, how do they benefit from such a process, and with what consequences? In the context of a highly decentralized control rights (both de jure and de facto) over local resources_-including land, fiscal revenue incentives provide an important clue to addressing these questions. Specifically, while the central government has since 1994 reclaimed a substantial share of the tax revenues generated by TVEs and subsequently all industrial enterprises regardless of ownership, local governments have been assigned the exclusive right over an increasingly important tax category, viz. the business tax. This tax has been a driving force in China's urbanization process, as nearly half of these revenues are generated from the construction and real estate sectors. In addition, since urbanization helps spur local GDP growth, it also enhances the career prospects of local officials (Xu, 2009).

Indeed, evidence does show that business tax has replaced both value-added and enterprise profit taxes as a new source of local governments' budgetary revenues. However, it is the monopoly right that the central state assigned to local governments over the conversion of farmland to non-arable usages that has powerfully whetted the local governments' fiscal appetite. Blessed with escalating land prices (especially for commercial and real estate developments in premium locations) on the one hand and artificially low compensations (based on the value of agricultural land use) on the other, many local governments-especially those in the rapidly developing coastal areas - have pocketed "windfall profits" from this state-induced urbanization process. As with the wide array of fees that users of converted farmland are made to pay to local governments and kept under the “extra-budgetary” or unsupervised category, 
land conversion income or the market price of land that developers pay for its use is similarly unsupervised. Evidence further suggests that land conversion income constitutes the biggest source of unregulated and unshared revenue for many local governments.

As with the effect of fiscal decentralization on the explosive growth of TVEs in the 1980s, the strong fiscal incentives provided by the 1994 reforms have led to two social problems; bearing in mind that fiscal decentralization is part of regional decentralization and that local governments are able to control enormous amount of resources within their jurisdictions. The first is that this "land-revenue incentive" has predisposed local governments to engage in farmland conversion at rates that not only endanger China's stock of arable land, but also subject large majorities of farmers to losing their primary source of livelihood with minimal compensation. And that is because, despite their being the nominal owner, the prevailing compensation principle as designed by the central government somehow confines farmers' rights in land to basically an "agrarian” usage; once land use is changed and ownership converted (from collective to state), these "agrarian rights” cease to exist. In other words, farmers would only be compensated according to the value of crop production, which is meager in comparison to what the local governments would obtain in selling these converted rights, in particular if the latter are based on commercial and real estate usage. Clearly, the Chinese government needs to address the twin problems of protecting farmers' property rights as well as halting the unabated loss of arable land in its reforms ahead.

The remainder of this chapter is organized as follows. In the next section we provide a descriptive analysis of "regional decentralization authoritarianism" as a general context for understanding China's reform strategy (Section 2), followed by a brief discussion of the fiscal contracting system and the powerful incentive effects it has had on local officials in developing the non-state local economy (in particular the TVEs), in Section 3. In Section 4 we show the connection between fiscal recentralization and the demise of TVEs and subsequently also the waning interest of local governments in promoting enterprise growth, whereas Section 5 examines the new set of incentives that powerfully set the local states to keenly engage in hastening urbanization or specifically land conversion. Section 6 then looks into the problems of 
this urbanization strategy both from a resource-erosion (of farmland) standpoint but more so from the perspective concerning the violation of farmers' property rights. Section 7 provides a brief conclusion.

\section{Regional decentralization authoritarianism}

In sharp contrast to all other formerly centralized economies where specialization and monopoly is an outstanding feature China had never organized its economy in a highly centralized manner - even in its heyday as a command economy (Naughton, 2007). This may explain why, when reforms commenced in China the number of products directly under the central plan was a mere 791—compared with over 12 million in the former Soviet Union, and the number of ministries directly under the central government's control less than 30-compared with 62 in the Soviet in the late 1970s (Xu, 2009). By further devolving the responsibilities of developing the local economies to regional governments the "Chinese-style" economic reforms only deepened this long-embedded decentralizing proclivity (Shirk, 1993). Consisting of a region-based multi-level hierarchy, in 2005 the central government directly controlled less than $4 \%$ of all industrial employees nationwide-already the largest economic sector in which it has had direct involvement.

An overriding goal of economic reforms is to improve economic efficiency, and the key to achieving that is to invigorate competition. The Chinese state achieved that important goal via regional decentralization, which essentially consists of two core elements. The first is, given its “initial conditions” (of being already highly decentralized) the state devolved property rights to various levels of regional governments to directly set up and manage enterprises of varying ownership types appropriate to their levels, and have them compete with each other on a regional basis. Secondly, equally important is that regional governments were provided with strong incentives to develop their economies via enterprise competition. In addition to granting these local governments de facto property rights over both (the smaller) state-owned and collectively-owned enterprises, which accounted for the majority of enterprises in China, the state has effectively put into place a "nested” system of personnel control by which to reward officials who have proven track records of moving their economies forward with promotion (and "rotation" in some instances). 
More specifically, this “developmental” incentive was further invigorated by the adoption of a "fiscal contracting" system whereby local governments were entitled to retain that portion of the revenue in excess of the remitted amount that it negotiated with the central government; ${ }^{3}$ a system with incentive properties analogous to that of a "fixed rental" system and which therefore has the effect of encouraging the “tenant”-the local government—-to seek more revenues (more below).

But decentralization does not always create strong incentives to regional officials for regional economic growth, hence the intriguing question is what makes China special in providing strong incentives to regional officials for economic development, and is there empirical evidence to bear upon the effectiveness of a basically decentralized regional economic operations nested within a hierarchy of centralized personnel control. Below we provide some clues to these related questions.

For regional decentralization and competition to work the center must be able to observe the true effort of regional officials — a dauntingly formidable task given that typically information is "impacted” within regions (Williamson, 1985). While the principal is unable to observe effort, fortunately outcome can be observed. Specifically, competition between regional officials can be evaluated among regions of comparable levels of development through a ranking system that resembles a tournament competition; which, as economic theory shows, is an effective mechanism for differentiating effort and accordingly performance. But two conditions must be met in order for a regional tournament competition to be feasible. First, the central government must be able to eradicate collusion between local or regional governments because collusion among regional officials could destroy competition. Fortunately, this condition is made possible by the fact that Chinese regionsespecially those at the county levels-are relatively self-sufficient and nonspecialized. To the extent that each region contains multiple economic sectors, it weakens interdependence between regions, as it enables local governments to carry out and coordinate most economic activities within their own jurisdictions.

\footnotetext{
${ }^{3}$ Jean Oi (1999) describes this revenue-sharing fiscal contracting system most succinctly: "Revenue sharing is a process in which local governments down to the level of township have the responsibility for collecting all nationally set taxes and then turning over a portion of this revenue to the next higher level. Those who have increased their tax revenues are allowed to keep the major portion of the increase. The provisions of revenue sharing are formalized in fiscal contracts between the central state and each of its provinces, between each province and its prefectures, between each prefecture and its counties, and between each county and its township.” (p. 29)
} 
Secondly, for regional tournament competition to work, it is also important that each region and the industrial sectors contained therein face broadly similar exogenous conditions, as that permits the center to compare the relative performance of regions - a more accurate and relevant yardstick for evaluating actual performance. ${ }^{4}$ Based on data that contains industry classification codes and location codes for each firm, Maskin, Qian and Xu (2000) find that the Chinese regions are indeed "alike"; their empirical results suggest that regional tournaments do work better than the alternative "ministerial” tournaments—one that resembles the highly specialized and monopolistic features of the formerly centrally planned economy-in providing high-powered incentives to local officials. Similarly, using data covering 344 top provincial officials for the 1979-2002 period, Chen, Li and Zhou (2005) find that each official's performance relative to her immediate predecessor does have a significant impact on her promotion. Using a panel dataset that covers 254 provincial leaders who had served in 28 Chinese provinces from 1979 to 1995, Li and Zhou (2005) similarly show that regional officials were indeed strongly motivated to promote regional economic growth. Specifically, a higher GDP growth rate in a province significantly improves the likelihood of promotion of provincial leaders-a result that underscores the underlying assumption that the central government makes promotion or turnover decisions based on a performance score of these leaders.

That there exists an intimate relationship between the performance of regional officials and their career prospects is indeed well documented in a number of studies. Tsui and Wang (2004), for instance, show that $60 \%$ of the targets required of leading provincial officials are related to “economic construction”. Moreover, the lower the level of regional governments the more concrete the stipulated targets become (Edin, 2003). At the lowest administrative levels, viz. the township and village levels, party secretaries and township heads are required to fulfill three categories of performance targets, with the fulfillment of the "hard" targets (consisting specifically of economic development plans most notably per capita GDP growth and tax revenues quotas) tied intimately to the award of bonuses and promotion (or political rewards) (Whiting, 2000). At the county level, for instance, Edin (2003) has observed that top-ranking

\footnotetext{
${ }^{4}$ For example, even if the tasks of agents are similar but if outside random factors that agents face do not follow the same distribution the principal would be unable to compare the performance of one agent with that of the other even if the absolute performance of both can be observed.
} 
township officials have been promoted to positions at the county level, whereas well performed municipal officials even transferred to other provinces as governors (Xu et al., 2007). In this context, an important question is whether the incentive embedded in this kind of "yardstick competition" serves the intended purpose of spurring regional economic growth. Before answering this question it is important that we include in our discussion the unique importance of fiscal decentralization-a core element of regional decentralization-in China’s reform process.

Fiscal revenue incentive and the rise of TVEs

The "career incentive" embedded in the kind of regional decentralization authoritarianism outlined above explains the powerful incentives bestowed upon regional governments in developing the economies under their jurisdictions. Growth of per capita GDP, employment and tax revenues, among other performance indicators are the important metrics upon which their careers within the Party and the government crucially depend. Another important part and parcel of the regional decentralization strategy was fiscal decentralization. The fiscal reforms implemented in the 1980s dramatically changed the incentives for local governments. By ceasing to guarantee upper-level budget allocations to meet local expenditures, local governments had to rely primarily on revenues created within their own jurisdictions. They were granted control rights over both revenues and profits generated by these endeavors. An important part of the revenue came from the development of non-farm enterprises (Qian and Xu, 1993; Oi, 1999). This shared arrangement of fiscal revenues between two immediate levels of government has had the essential incentive property of a "fixed rental" contract, whereby the "tenant" gets to keep more the more revenues it manages to generate. ${ }^{5}$

As part of regional decentralization, fiscal decentralization played an important role in the massive and rapid development of a non-state sector in the Chinese economy since around the mid-1980s, of which township and village

\footnotetext{
${ }^{5} \mathrm{Oi}$ (1999) notes that the terms of the contracts vary from one place to another; while some areas employ an overall ratio such as 70:30 (with the level of government from which the taxes are collected keeps 70\% whereas the immediate supervising level keeps 30\%), others merely pay a fixed lump-sum quota to the next higher level (p. 29). "Regardless of the system of revenue sharing in effect, increased tax collection guarantees a locality an increase in tax revenue” (Oi, 1999: 30).
} 
enterprises (hereafter TVEs) was a key component (Qian and Xu, 1993; Jin, Qian and Weingast, 2005). Indeed, with no more than a modicum of non-agricultural enterprises before the early 1980s TVEs already counted for roughly $80 \%$ of output of the non-state sector in less than a decade. Between 1981 and 1990, total industrial output of TVEs grew at an average rate of $28 \%$, and as such had been the main engine of growth of the Chinese economy. It is also well known that the productivity of TVEs was distinctly higher than that of the SOEs (Weitzman and Xu, 1994).

County governments benefited enormously from the development of TVEs, primarily because they were able to share tax revenues that these enterprises generated under the fiscal contracting arrangement and that the lion's share of the increases in tax revenues (the industrial-commercial taxes) had come primarily from township and village enterprises. Starting at a modest base of a little over 2 billion yuan in 1978, taxes grew to 205.8 billion yuan by 1995—an increase of more than tenfold (Oi, 1999: 36). ${ }^{6}$ As long as the variety of taxes that county-level governments were able to capture was based on production (product tax), income (value-added or transaction tax), and turnover (business tax) rather than profits per se, it had powerful incentives to expand TVEs without paying much regard to their profitability.

A similar incentive existed for the township governments. Not only were they entitled to sharing the bulk of tax revenues (e.g. 70\%), they were also keeper of enterprise income or simply profit tax, which formed an additional source of "horizontal" income essential for, among other purposes financing the provision of local public goods. ${ }^{7}$ Depending on the level of tax revenues, local governments needed not exert the same amount of effort in collecting taxes. By taxing at the minimum rather than maximum levels, which is viable in a context where the economy was still growing, some local governments may decide to provide greater incentives for enterprises under their jurisdiction to become more efficient. ${ }^{8}$

\footnotetext{
${ }^{6}$ Although county-level industrial firms continued to be the bedrock of county-level income and taxes, its tax contribution had decreased as a proportion of total revenues over time as TVEs grew (Wong, 1991; Naughton, 1992).

${ }^{7}$ In 1985 enterprise income tax was extended to township and village enterprises in replacing the industrial-commercial income tax (see Oi, 1999: 35).

${ }^{8} \mathrm{Oi}$ (1999), for instance, has found that rich counties tended to grant more tax breaks than did poor counties (p. 38).
} 
In addition to reaping the direct benefits of increased fiscal revenues, the development of TVEs also had the anticipated effect of accelerating GDP growth, which in turn served to enhance local officials' career prospects (Xu, 2009). Thus, local officials had been keen in developing the TVEs, such as by procuring loans from financial institutions under their jurisdiction to finance their expansion. In 1995, for example, bank loans accounted for as much as $64 \%$ of all credit incurred by TVEs; more startlingly, overall debt-equity ratio of TVEs even outweighed that of the SOEs (Kung and Lin, 2007: 573). In fact, even up until 1999, when some provinces already underwent large scale privatizations of TVEs, TVEs continued to achieve steady growth in tax revenue; only the "efficiency" of tax revenues - that is, tax revenues measured in terms of per unit of sales and profits - declined (more below on this).

\section{Fiscal Reform and the Decline of TVEs}

By the 1990s concerns had mounted that the reform strategy of allowing localities to benefit disproportionately from local economic growth by assigning the regional governments residual income rights over tax revenues and enterprise profits was achieved at considerable costs; to the extent that the "central state capacity" had been severely weakened. For instance, the central government's share of revenue in overall budgetary revenue dwindled precipitously from 40.5\% in 1984 to $22 \%$ in 1993. Some scholars even contend that the state had, as a result of fiscal decentralization lost its capacity to macro-manage the economy, which may in turn led to political instability (e.g., Wang and Hu, 1993; 2001). Responding to this concern, the state tightened fiscal control over revenues in 1994 by redefining tax rights between the national and regional governments and took more in taxes from the localities. By reclassifying tax categories and assigning tax rights based not on who owns an enterprise, the ensuing reforms essentially subjected a disproportionately larger revenue to revenue sharing. In particular, the central government wrestled from local governments the exclusive rights over a newly established consumption tax over such inelastic consumption products as beer, hard liquor and cigarettes, as well as reassigned a hefty $75 \%$ of the transaction or value-added tax to itself. As Fig. 1 clearly shows, this measure drastically altered the proportion of revenues shared between the national and sub-national governments. For the latter, the ratio 
plummeted from an apex of $80 \%$ before 1994 to roughly 45\% afterwards and became stabilized at that level thereafter.

Fig. 1 about here

While the central government has since the 1994 fiscal reform reclaimed a substantial share of the tax revenues generated from TVEs and other industrial enterprises, local governments were compensated by gaining other rights in the process. Specifically, they were assigned the exclusive right over what is to become an increasingly important tax category, viz. the business tax. Moreover, local governments were given the official recognition for being the de jure owner of not merely the enterprises established under their jurisdiction but more importantly also of land (the $15^{\text {th }}$ National Congress of the Communist Party of China, 1997; Xu, 2009); which for some is going to be an enormously important revenue source. As we shall soon demonstrate, the rights with which the central state assigned to the local governments both in the disposal of local firms but more so in the conversion of farmland to non-arable usages have crucially shaped the incentives and accordingly behavior of the local governments in the post-TVEs era.

The implications of the fiscal reform package on local finances and on the development strategy of local governments are profoundly far reaching. Here we confine our analysis to the eventual demise of TVEs - once an engine of growth of China's economy during the first twenty years or so of the reform. As rehearsed earlier, local officials at both the county and township levels had especially strong incentives to expand TVEs because of the (transaction) tax revenues that these enterprises remitted and their career concerns. These advantages were however shortlived; once the central state began to expropriate the lion's share of the tax revenues associated with TVEs local governments were no longer as enthusiastic in their expansion and from then onwards the entire TVE sector began to decline (Kung and Lin, 2007).

Decline of the TVE sector is attributable in particular to both a reduction of investments in, and privatization of the sector. The reasons behind the reduction of investments and privatization were variegated; here we focus primarily on the impact 
of the 1994 fiscal reforms. ${ }^{9}$ Indeed, despite a secular rise in TVE tax revenues, "tax "efficiency" of the TVE sector — measured in terms of tax revenue per unit of sales and profit rate-had in fact declined over time. This is due to a weakening in the local officials' monitoring capacity and their growing inability to obtain credit to help finance TVEs expansion. Nationwide evidence indicates that as a result the relative importance of TVEs declined (Kung and Lin, 2007).

The 1994 fiscal reform was one of the major factors that further pushed the nationwide privatization of TVEs. In light of the drastic shift in fiscal rights between the national and sub-national governments over particularly the transaction tax (from fully $100 \%$ before 1994 to only 25\% thereafter), it is most likely that the benefits of TVEs expansion at the margin would decline precipitously, whereas the costs of expansion —in terms of obtaining loans and maintaining profits—-would increase markedly. Given other factors, this may further convince local governments to privatize TVEs. The statistical significance of a negative coefficient of time trend in Kung and Lin’s (2007) estimations may be interpreted as capturing this secular trend of privatization triggered by the change exogenously imposed by the 1994 fiscal reforms.

From Industrialization to Urbanization-A new source of fiscal revenue incentive

In market economies industrialization and urbanization usually go hand in hand with each other. The case in China, however, is somewhat different. Owing to restrictions that the Chinese government has placed upon rural-urban migration (since around the mid-1950s), the two processes have been made artificially separate. This is especially the case before the 1978 economic reforms, when industrial growth was spatially concentrated in urban areas, on the one hand, and rural-urban migration held tightly in check—via the household registration system or hukou—on the other. Although the physical movement of people have been greatly relaxed in the last quarter of century and urbanization has since then proceeded at a much faster clip than previously, as over hundreds of millions of villagers have migrated to the urban

\footnotetext{
${ }^{9}$ The existing literature predicts that when the protection of private property rights has improved, when asset markets are better developed, and/or when large-scale migration has occurred, the ownership advantage of TVEs tends to become sub-optimal and privatization is more likely to occur. Evidences are consistent with these predictions (Xu, 2009).
} 
areas to take advantage of the non-farm employment opportunities, the hukou system — essentially an "apartheid” institution that separates the urban populace from its rural counterpart via the rights to a wide range of "entitlements” (such as the rights of their children to education for instance)—remains restrictive in many respects. Moreover, a case can also be made that urbanization has been slowed also by the fact that a good part of China's post-reform industrial growth has spatially concentrated in townships and villages. While the reassignment of rights over transaction or valueadded taxes undoubtedly led the local governments to shed a large collection of nonprivate enterprises many of which were likely unprofitable, the 1994 fiscal reforms did not stifle rural industrialization, as local authorities were still left with exclusive claims over enterprise income or profit tax, and which therefore rendered them to focus parsimoniously on enterprise efficiency. It is thus no coincidence that the privatization of TVEs, which began in earnest around 1995, had merely led to a change in ownership rather than elimination of many of these industrial enterprises.

What made local governments shift their development strategy from fostering enterprise growth to that of urban growth was the reassignment of rights over enterprise profit tax in 2002. The 1994 fiscal reforms left both local enterprise income tax and individual income tax (alongside a number of other tax categories) to the local governments as sole residual claimants (Oi, 1999: 55). Similar in spirit to the 1994 reforms, the central government proposed to appropriate, from 2002 onwards $50 \%$ of the enterprise profit tax (increased to 60\% in 2003) — a change with the effect of robbing local governments the incentive of improving enterprise efficiency regardless of ownership. To make up for the lost revenues resulting from these fiscal reforms local governments must look elsewhere. Fortunately for the local governments the central state has not proposed to share with them what is to become an important source of tax revenue, namely the business tax, which consists primarily of taxes levied upon the construction and real estate industry and to a lesser extent also the service sector. As the Chinese economy continues to grow and so the country is concomitantly going through a secular process of urbanization, construction and real estate development has become the cornerstone of this development process, to the 
extent that it profitably provides a new source of tax revenue to local authorities, who, needless to say are only all too happy to ride on this emerging wave. ${ }^{10}$

The changing relative importance of these two taxes in overall budgetary revenues of local (county-level) governments is reflected in the growing share of business tax from 20\% in 1994 to 25\% in 2003, on the one hand, and the decline of transaction tax from $22 \%$ to $18 \%$ during the same period on the other (Zhou, 2006: 112). As shown in Figure 2, the construction and real estate (CRE) sectors have been a major contributing source of business tax revenue. Moreover, its relative importance had increased over time-from 33\% in 2001 to almost one half, 45.5\%, in 2004. Not surprisingly, therefore, that one of us found, in an in-depth study of local finance in a rapidly developing county in Zhejiang - a province located in the eastern coastal seaboard-that business taxes collected from the CRE sector accounted for $17 \%$ of the land-and-construction related budgetary revenues, which in turn accounted for nearly $40 \%$ of total budgetary revenues (38.4\% of roughly 12 million yuan, Figure 3, Zhou, 2007). Against this background, it becomes apparent that as much as $17.6 \%$ of the farmland loss (due to conversion) between 2000 and 2005 was occupied by construction for a variety of purposes, with the magnitude rising over time (more than half, 58.7\%, of the farmland converted in 2005 was earmarked for construction, Ministry of Land and Resources, 2006). The recentralization of fiscal rights since 1994 notwithstanding, the reforms in question has unwittingly left a "tail” for local governments to engage in a gamut of construction and infrastructure projects in China's accelerating urbanization process. But it is land development or specifically the conversion of farmland to non-arable usage that provides local governments with even more powerful incentives to "urbanize” China.

Figs. 2 and 3 about here

The benefit of pursuing an "urbanization" strategy is by no means confined to being the sole residual claimant of the business tax. By converting farmland for a variety of development projects local governments are able to both collect fees (fei) associated with land conversion and, even more lucratively entitle to a land conversion income (tudi churang jin) —an income stream over which it has been

\footnotetext{
${ }^{10}$ The percentage of the Chinese population classified as "urban"- those residing in township and above-increased from less than 18\% in 1978 to 43\% in 2006 (State Statistical Bureau of China, 2007).
} 
assigned exclusive rights by the central government (more below). As fees are classified as "extra-budgetary” revenues, local governments are allowed to lay exclusive claims over this income source, which as we can see from Figure 3 amounted to over half (51.5\%) of the surveyed county's overall “extra-budgetary” revenues in 2003. For rapidly developing counties that command a price premium on their locations, these "extra-budgetary" land revenues can indeed be substantial, and which must have usefully substituted for the loss revenues which have been channeled to the central government as a result of the 1994 and (perhaps to a lesser extent) also the 2002 fiscal reforms.

But the biggest gain of all from converting collective farmland into non-arable usages comes distinctly from land conversion income-a revenue stream to which local governments have been assigned exclusive rights—also commencing $1994 .^{11}$ Although conversion of cultivated land for urban and rural construction can be dated to the late 1980s, thanks initially to the rural housing construction boom and subsequently to industrial, transport and urban developments, the magnitude of revenues was miniscule back then. For instance, the amount of fees collected from land leasing totaled only 242 billion yuan nationwide between 1987 and 1994 (State Land Management Bureau, 1998, cited in Lin and Ho, 2005), which pales greatly in comparison with the 901 billion yuan or $90 \%$ of the entire revenue received during the three years between 2001 and 2003.

That the acceleration of land conversion is a recent phenomenon can be clearly illustrated in Figure 4, where we plot both the incidence and magnitude of land conversion for the period 1993-2005 from figures provided by the Ministry of Land and Resources. There we can see that it is only after 1999 did both the incidence and magnitude exhibit a steeply upward trend, up until 2003 when the state became so worried that China would soon deplete its arable land below its lowest threshold required of food self-sufficiency that it began to clamp down on the "excessiveness"

\footnotetext{
${ }^{11}$ It was first introduced in 1989 as a shared arrangement between the central and regional governments under the provisional regulation "Temporary regulation on the transfer of use rights of state-owned land in towns and cities”. When it was amended in 1994, the state allowed regional governments to appropriate in full the proceeds from transferring the use rights of state-owned land.
} 
of land conversion, at a time when land prices-especially those in premier locations-already commanded hefty valuations (more on this below). ${ }^{12}$

Figure 4 about here

In an attempt to slow down the conversion of farmland by regional governments, the Ministry of Land and Resources set a quota on the maximum quantity of land authorized for conversion in a policy document in 2001, beyond which limit it would be considered illegal. But if Zhou's (2007) micro-study realistically approximates the reality, the incredibly colossal magnitude of "land conversion fee” received by governments in the rapidly developing counties (that it could be as large as the budgetary and "extra-budgetary" revenues combined) implies that it would not be an easy task for the central government to effectively put a brake on land conversion. The fact that regional governments have been assigned monopoly rights to receive this lucrative, unregulated income source in its entirety must have powerfully whetted the fiscal appetite of regional officials in hastening the pace of land conversion.

This may help explain why, even though authorized (or "legal”) land conversion activities declined since 2003, un-authorized (or “illegal”) ones had sharply risen during the same year; this is especially so with regard to land area (Figure 5). Escalating land prices — especially those in premier locations, on the one hand, and the low costs of land compensation, on the other, were the likely culprits. The prices of land in premier locations have likely appreciated by leaps and bounds in recent years that, for instance eight premier sites in the municipality of Hangzhou were expected to fetch 6 billion yuan from the cash-flushed domestic developers (SCMP, August 15, 2007, p. 3). Such lucrative revenues have to be set against the exceedingly low costs of land conversion incurred by regional governments—subject of our next section. For instance, Zhou (2007) finds that compensations incurred by a county government in Zhejiang Province accounted for an extremely tiny fraction, $1.59 \%$, of the selling price. Even after paying various fees to the relevant government departments, total costs of land conversion only made up $4.75 \%$ of overall land conversion revenues. And in the less lucrative instance of residential and mixed

\footnotetext{
${ }^{12}$ Statistics show that farmland decreased by as much as 120 million $\mathrm{mu}$ ( $1 \mathrm{mu}=0.0667$ hectare) between 1996 and 2005 or 6.6\% of the total arable land (Ministry of Land and Resources, 2006).
} 
(commercial and residential) usages the pertinent percentages accounted for only 13.84 and 9.16, leaving colossal profits to be reaped by the municipal government. Similarly, Zhou Qiren (2004) has also shown that in selling one mu of arable land the township government of Maichen in Xuwen County in Guangdong Province had to paid only 40,000 yuan, which, when set against the average selling price of 0.88 million yuan per mu the township government there could easily cover the cost from selling only four mu of land; the Maichen township government sold $90 \mathrm{mu}$ of land in this instance and made a windfall profit.

Small wonder regional governments have increasingly turned to auctioning land usufruct rights to commercial and real estate usages instead of either industrial (in the form of “development zones” or kaifaqu) or public welfare projects (gongyi shiye xiangmu) such as roads and highway construction, schools and hospitals, etc.; the latter a trend up until the mid-1990s (Lin and Ho, 2005: 424). Regional governments' waning interest in allocating land to public welfare projects can be easily explained by the fact that land is typically provided for free in such instances. Moreover, regional governments have to provide subsidies typically required in developing land for these projects. And while industrial usage is in principle also a revenue generator, fierce competition among localities could easily drive prices down (Q. Zhou, 2004), to a point where villagers became so upset with the township government for having charged an unconvincingly low price that they suspected the local officials of corruption. Some villagers were so angry that they even robbed the cadres' houses (Ming Pao, 2007, May 8 and 11, A29). Once again, Zhou’s (2007) study of the three municipalities/counties in Zhejiang Province demonstrates this point most clearly. Whereas the average price of industrial land varied only narrowly between 12,000 and 15,000 yuan per mu between 1999 and 2003, the lowest commercial price was 34,000 yuan in 2001 and a whopping 182,000 yuan the year after.

The hefty prices that premier locations fetch is however not balanced by the appallingly low compensation that farmers receive in relinquishing their land. As we shall explain in further detail in the next section, apart from exceeding the quotas set by the state and the delays in compensating farmers overall low compensation is actually part and parcel of the institutional design and is thus not illegal. The Land Management Law of 1986, which spells out in detail the exact compensation to be 
paid to farmers in the event of land conversion, is essentially premised on the agricultural value of land, whereas the sale price of the converted land is determined by non-agricultural value, between which lies a colossal gap in monetary value (especially where land is converted for real estate development). In other words, as long as local governments convert land within the limits set by the central government and compensate the farmers according to legal stipulations, which is set at 6-10 times the average crop yield of the previous three years, plus a resettlement allowance set at 4-6 times the average yield of the previous three years, and lastly a locally determined crop compensation fee, land conversion conducted in accordance with these stipulations is by no means illegal. Indeed, local governments are assigned the rights to retain the profits from land conversion and are expected to deploy them rationally to developing the local economy.

\section{Land Conversion: Low Compensation a Violation of Farmers' Property Rights?}

The extraordinarily strong incentives of local governments to boost fiscal revenues have far reaching consequences both for China's arable resources and statepeasant relationships with regard to competition over these scarce resources.

Although the state has officially set quotas on land conversion, local governments have strong incentives to circumvent the law. For instance, of the 837 appeal letters received by the central government in 2003 concerning land issues, fully 55\% was related to illegal land expropriation and occupation of collective land (Institute of Rural Development Research, Chinese Academy of Social Science, 2003: 14). ${ }^{13}$ This finding is consistent with the evidence that unauthorized conversion increased in 2003 amidst the decline in authorized conversion (Figure 5). Although it receded in 2004, by 2006 the Ministry of Land and Resources was still forced to issue an urgent circular to local officials who approved new land acquisitions without authorization from the central government. The circular warned them gravely of the possible consequences of party disciplinary sanctions, and also called upon the supervisory ministry to ensure better enforcement in the crackdown. In light of the trend that an average 200,000 hectares of farmland had been converted annually into non-arable usage (Chen Xiwen, cited in Wang, Hongru, 2006: 3), in 2007 China’s premier Wen

\footnotetext{
${ }^{13}$ The next major reason, which accounted for $23 \%$, pertains to compensation being "too low or misappropriated”.
} 
Jiabo warned gravely that China must rigorously protect its arable resources as it could ill afford to fall below the minimum threshold of 1.2 million square kilometers of arable land required for food self-sufficiency.

Even more seriously, as unauthorized land conversions often involved forced evictions of farmers off their land and homes, inadequate compensation, deferred payments or downright embezzlement, they threatened social stability. Indeed, the "land issue" (tudi wenti) topped the list of the three key major agrarian issues (sannong wenti) — accounting for $68.7 \%$ of all responses according to a CCTV telephone survey conducted in 2004. It is also not surprising that violent conflicts between villagers and local police over land disputes had repeatedly occurred since the early 2000s, with county and municipal governments being notable villains (Yu, 2005).

To better understand the nature of property rights in land in the Chinese context it is necessary to invoke a little bit of history here. In a nutshell, de jure private ownership in land with respect to the bundle of use, income and transfer right has ceased to exist in China after the Communist Party came to power in 1949 and collectivized agriculture in successive stages in the mid-to-late 1950s. Since decollectivizing its agriculture in the early 1980s, use and income rights have been reassigned to the farm households through land leasing contracts which they signed with the village authorities (cun jiti). Neither the right to alter the land's usage nor to transfer it to another party was conferred to the farmers, however. This crucial right to transfer the foregoing bundles of rights has remained firmly in the hands of the state and in part of the village authorities. But as an increasing number of farmers leave for long distance off-farm employment opportunities, it becomes apparent that it is necessary for the state to relax the grip placed upon farmers from transferring their use and income rights in land-at least temporarily.

It is in this evolving context of development that the state further extended farmers' rights by allowing them to temporarily transfer their use rights or simply renting. According to the new Rural Land Contracting Law (Nongcun tudi chengbaofa), enacted in 2002, farm households are allowed to sublease their land to other farm households. To ensure that farmers are able to enjoy this limited transfer right, the state has even gone so far as to prohibit the village authorities, the nominal 
owner, from periodically reallocating land among farm households in response to demographic change- - customary practice embedded in the collective ownership nature of China's arable land. Unfortunately, this protection of farmers' transfer right is confined to only arable land use; once land is converted to non-arable usage the statutory power of the Rural Land Contracting Law ceases to apply.

In fact, nationalization has been the only legal mechanism by which farmland, which is de jure collectively-owned, can be converted into non-arable usages. According to Article 63 of the Land Management Law of 1999, the legal statuses governing land conversion, farmers do not possess the right to convert arable land into non-arable usage; only the (nominal) owner, viz. the local authorities, are empowered to do so. Moreover, any non-arable usage of collective farmland requires a corresponding change in ownership—specifically from collective to state ownership (Article 43). Apart from the minimal compensation stipulated by the state and which therefore is liable to legal protection, China's farmers are thus subject totally to the whims of local authorities in the process of land conversion. As mentioned earlier, even in the best-case scenario where local governments observe the quota limits of land conversion and abide by the procedures of compensation, the massive hiatus between the "windfall profits" resulting from selling the farmland for commercial and real estate development on the one hand and the measly compensation made to farmers on the other has created an enormous sense of injustice from the latter's point of view.

In the process of land conversion local authorities have triggered serious conflicts with the farmers, who feel that they have been robbed of the bundle of rights assigned to them at the outset of the reform. From this vantage point it is thus ironical that, while the state has legislated to protect farmers' use rights by prohibiting local authorities from periodically reallocating land, it accords the same authorities the monopoly right to grab land away from the village community with only minimal compensation. Although they are nominally "members" of the village collective, farmers are basically unable to defend their collectively-held land rights against the local authorities. With this power bestowed upon them and, more specifically, with a clearly defined compensation formulae stipulated by the central state, many local authorities simply find it unnecessary to negotiate with the peasants for a fair 
compensation; the major binding constraint in determining compensation appears to be the threshold value of avoiding social unrest. Thus, although local authorities are supposed to act in the interests of the farmers, in particular in guarding their collective land rights, more often than not they have turned out to be robbers of valuable communal resources.

\section{Conclusion}

China's sustained economic growth since 1978 has occurred in a highly decentralized context of “yardstick competition” among regions facing similar external conditions. While the initial decentralization-based reform led to phenomenal success of industrial growth (in the form of TVEs) in many regions, the reassignment of fiscal rights over various tax categories and revenues have subsequently induced some local governments to focus disproportionately on "urbanization.” The key impetus behind this drive for "urbanization" lies in the conversion of farmland into commercial usage, and the construction and real estate sectors associated therewith. The exclusive income and monopoly rights of local authorities over land conversion have powerfully predisposed them to maximize their fiscal coffers at the expense of farmers’ rights in agricultural land. However, the legal rights with which local officials have been assigned and the biased incentives embedded in these rights have led to ever worsening social conflicts. To arrest these adverse tendencies the central government has endeavored both to cramp down on land conversion and development and to acquiesce the growing rural social unrest. However, a thorough solution would require more than mere piecemeal attempts to contain these problems; just as previous reforms, further reforms down the road of transition and growth similarly require a reconfiguration of existing institutions and their attendant property rights structure. 
Figure 1: Central and Local Governments’ Budgetary Revenues, 1978-2006

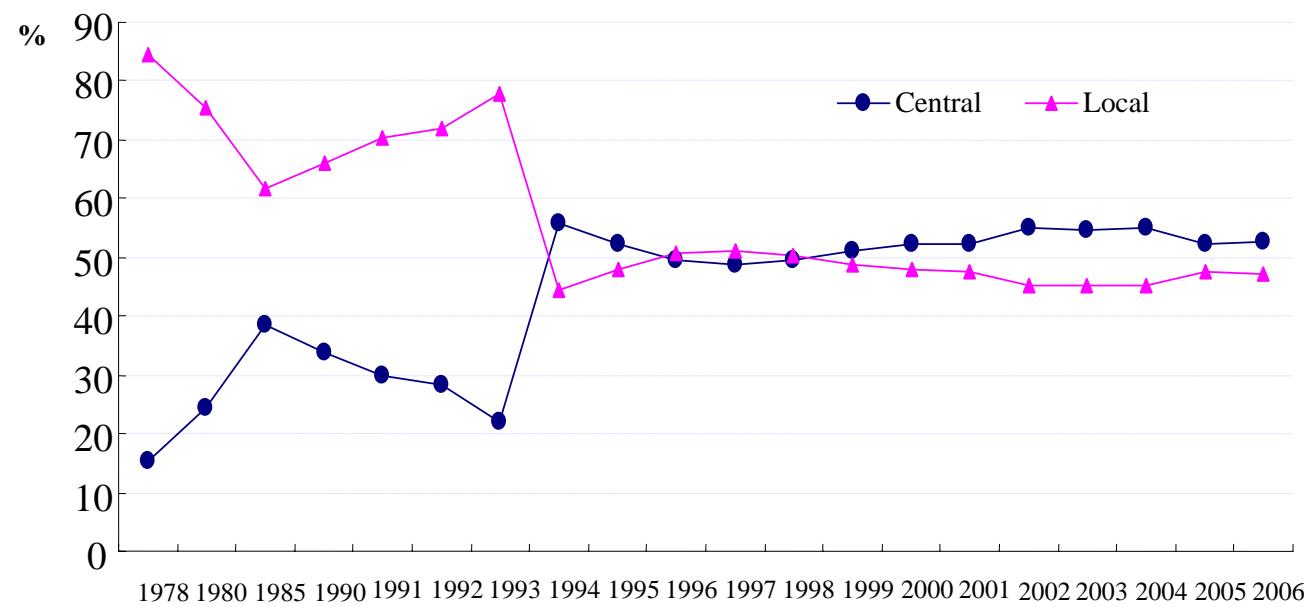

Source: A Compendium of Statistics for the 55 Years of New China, 1949-2004 (Xinzhongguo Wushiwu Nian Tongji Ziliao Huibian). Beijing: Zhongguo Tongji Chubanshe, 2005. 
Figure 2: Share of Construction and Real Estate Sectors in Business Tax, 2001-2004

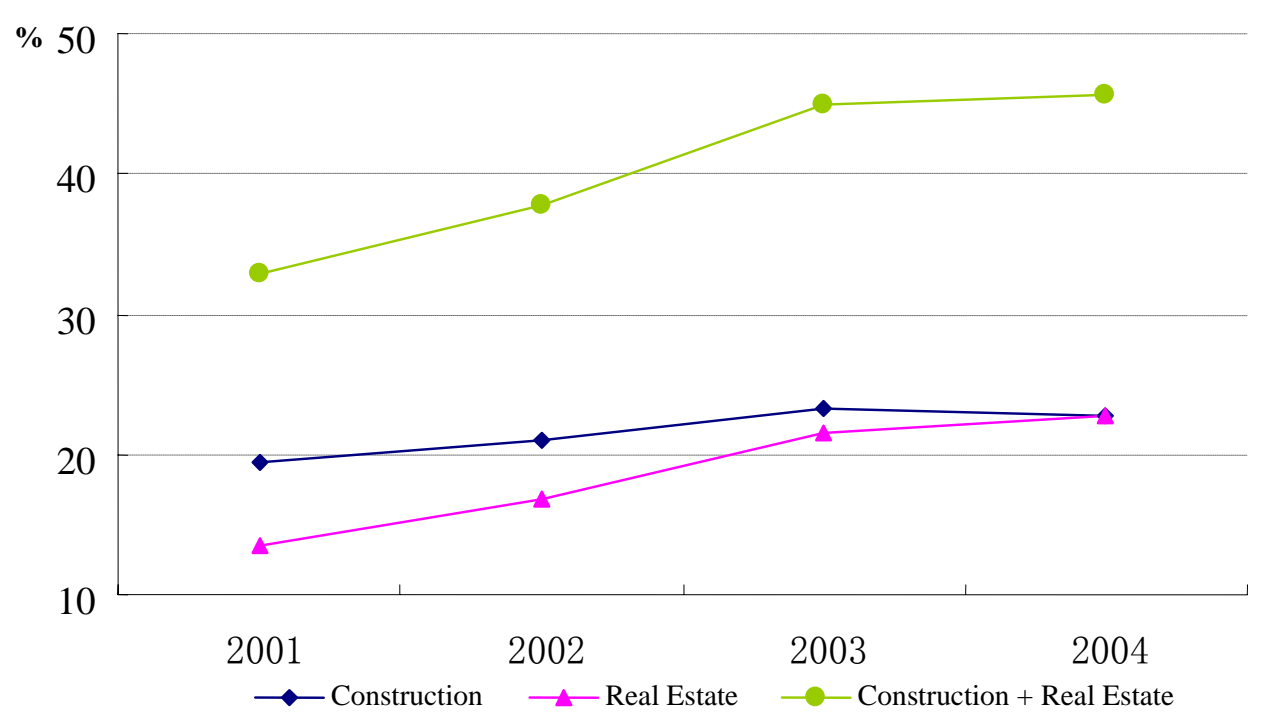

Source: The Taxation Yearbook of China, 2005 (Zhongguo Shuiwu Nianjian). Beijing: Zhongguo Shuiwu Chubanshe. 
Figure 3: Profits from Land Revenue in S County, Zhejiang Province, 2003 (Million Yuan)

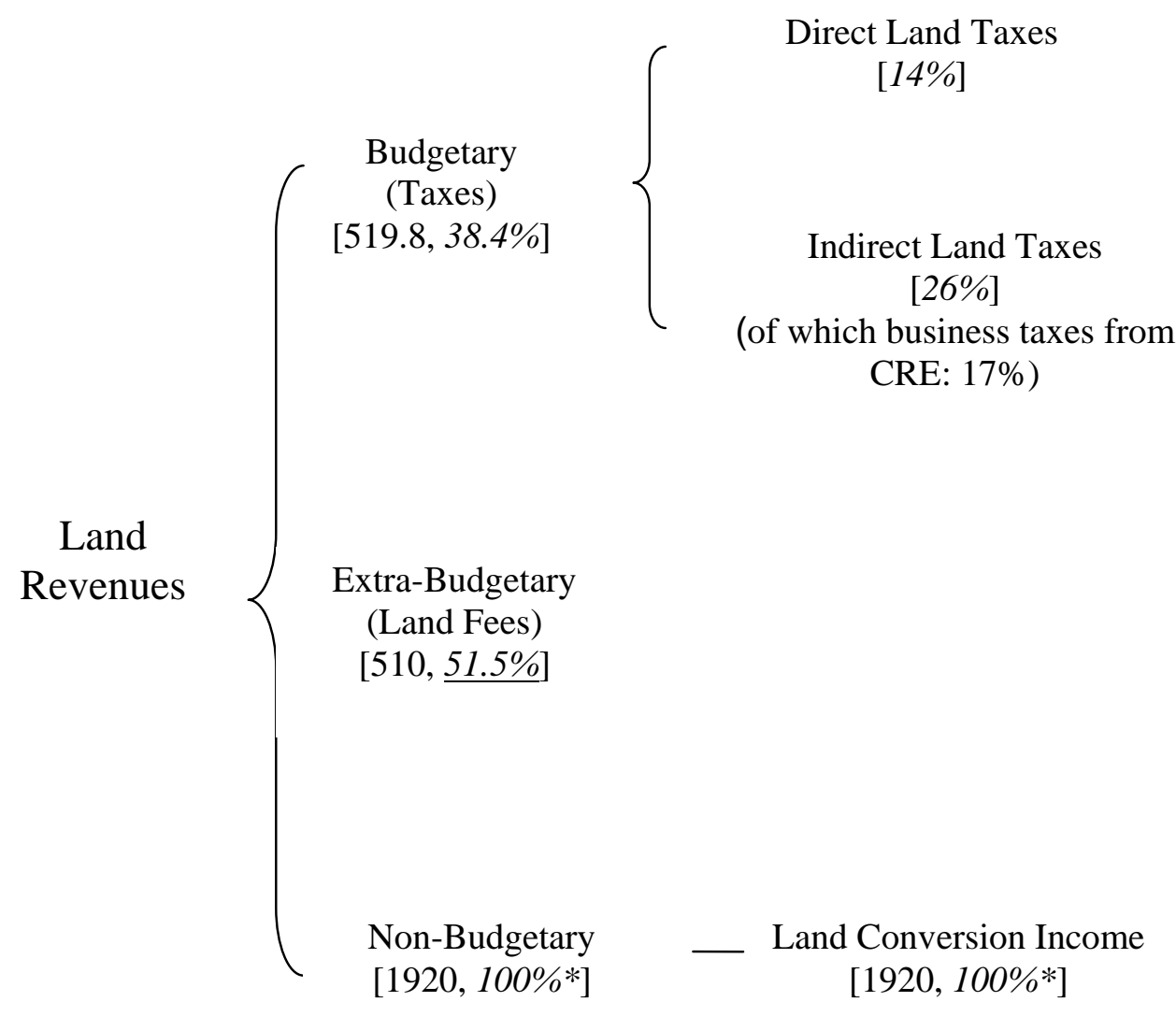

Note: $\mathrm{CRE}=$ Construction and Real Estate

$\%$ of budgetary revenue;

$\%$ of "extra-budgetary" revenue;

$\% *$ of "non-budgetary" revenue.

Source: Zhou (2007). 
Figure 4: Incidence and Magnitude of Land Conversion, 1993-2005

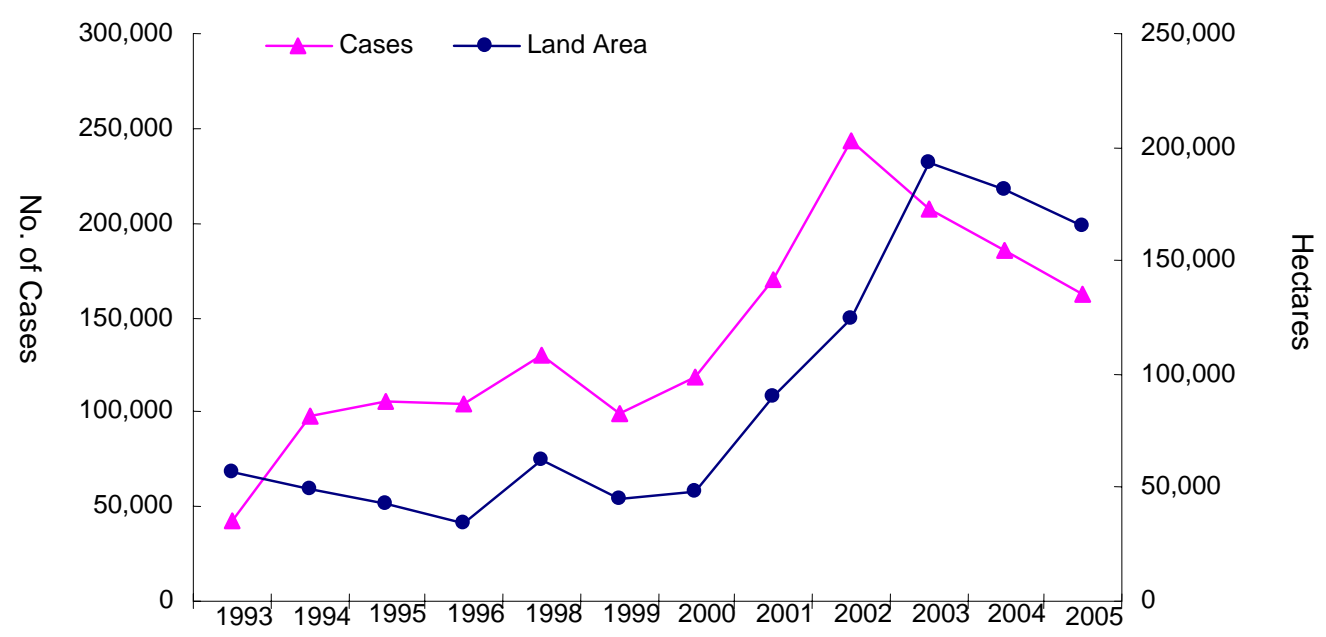

Sources:

The Land Yearbook of China, 1995-1997 (Zhongguo Tudi Nianjian, 1995-1997).

Beijing: Renmin Chubanshe.

The Land Resource Yearbook of China, 1999-2006 (Zhongguo Guotu Ziyuan Nianjian, 1996-2006). Beijing: Renmin Chubanshe. 
Figure 5: Unauthorized Land Conversion: Incidence and Magnitude, 1993-2005

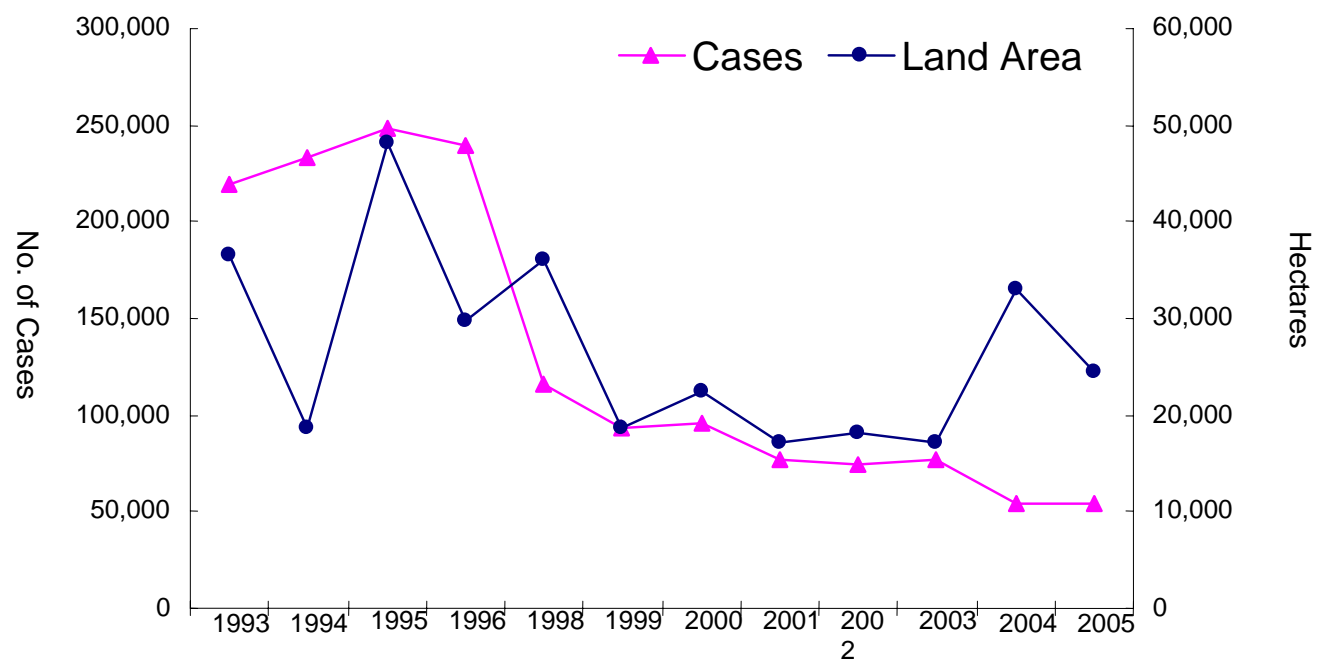

Sources:

The Land Yearbook of China, 1995-1997 (Zhongguo Tudi Nianjian, 1995-1997). Beijing: Renmin Chubanshe.

The Land Resource Yearbook of China, 1999-2006 (Zhongguo Guotu Ziyuan Nianjian, 1996-2006). Beijing: Renmin Chubanshe. 


\section{References}

A Compendium of Statistics for the 55 Years of New China, 1949-2004

(Xinzhongguo Wushiwu Nian Tongji Ziliao Huibian, 1994-2004). Beijing:

Zhongguo Tongji Chubanshe, 2005.

Chen, Ye, Hongbin Li, and Li-an Zhou (2005), "Relative Performance Evaluation and the Turnover of Provincial Leaders in China”, Economics Letters, 88 (3): 421-425.

China Ministry of Land and Resources (CMLR) (1999-2003), Zhongguo guotu ziyuan nianjian [Almanac of China's Land and Resources], Beijing: Zhongguo tudi chubanshe.

Edin, Maria (2003), "State Capacity and Local Agent Control in China: CCP Cadre Management from a Township Perspective,” The China Quarterly, 173: 35-52.

Editorial Committee (1995-1997), Zhongguo tudi nianjian [Statistical Yearbook of China's Land], Beijing: Renmin chubanshe.

Jin, Hehui, Yingyi Qian, and Barry Weingast (2005), "Regional Decentralization and Fiscal Incentives: Federalism, Chinese Style”, Journal of Public Economics, 89 (9-10): 1719-1742.

Kung, James K. and Yimin Lin (2007), “The Rise and Decline of Local Public Enterprises in China's Economic Transition,” World Development, 35 (4): 569-584.

Li, Hongbin and Li-an Zhou (2005), "Political Turnover and Economic Performance: The Incentive Role of Personnel Control in China”, Journal of Public Economics, 89 (9-10): 1743-1762.

Lin, Justin Y. and Zhiqiang Liu (2000), "Fiscal Decentralization and Economic Growth in China”, Economic Development and Cultural Change, 49 (1): 1-21.

Lin, George and Samuel Ho (2005), “The State, Land System, and Land Development in Contemporary China,” Annals of the Association of American Geographers, 95 (2): 411-436.

Maskin, Eric, Yingyi Qian, and Chenggang Xu (2000), "Incentives, Information, and Organizational Form,” Review of Economic Studies, 67 (2): 359-378.

Ming Pao (2007), "Land Expropriation in Shantou Induced Villagers' Attacks of Cadres [Zhengdi lianbao chongtu, shantou cunmin xiguan]”, May 8, A29.

Ming Pao (2007), "Villagers in Shantou Set Deadline for Factory Relocation [Shantou cunmin wei gongchang xianqi banzou]”, May 11, A29.

Naughton, Barry (1992), "Implications of the State Monopoly over Industry and Its Relaxation”, Modern China, 18 (1): 14-41. 
Naughton, Barry (2007), The Chinese Economy: Transitions and Growth, Cambridge, Mass.: MIT Press.

Oi, Jean C. (1999), Rural China Takes Off: Institutional Foundations of Economic Reform. Berkeley: University of California Press.

Qian, Yingyi and Chenggang Xu (1993), “Why China’s Economic Reform Differ: The M-form Hierarchy and Entry/Expansion of the Non-state Sector”, Economics of Transition, 1 (2): 135-170.

Shirk, Susan L. (1993), The Political Logic of Economic Reform in China. Berkeley: University of California Press.

South China Morning Post (2007), “Officials Warned on Illegal Land Deals”, August 15: 3.

State Statistical Bureau of China (2007), China Statistical Yearbook 2007, Beijing: Zhongguo tongji chubanshe.

The Land Yearbook of China, 1995-1997 (Zhongguo Tudi Nianjian, 1995-1997). Beijing: Renmin Chubanshe.

The Land Resource Yearbook of China, 1999-2006 (Zhongguo Guotu Ziyuan Nianjian, 1996-2006). Beijing: Renmin Chubanshe.

The Taxation Yearbook of China, 2005 (Zhongguo Shuiwu Nianjian). Beijing: Zhongguo Shuiwu Chubanshe.

Tsui, Kai Y. and Youqiang Wang (2004), "Between Separate Stoves and a Single Menu: Fiscal Decentralization in China”, The China Quarterly, 177: 71-90.

Wang, Hongru (2006), “Land Disputes Hasten the Reform of Land-Requisition Institutions” [Tudi jiufen jicui zhengdi zhidu gaige], China Economic Weekly, (9).

Wang, Shaoguang and Angang Hu (1993), Report on China's State Capability [Zhongguo guo jia neng li bao gao], Shenyang: Liaoning renmin chubanshe.

Wang, Shaoguang and Angang Hu (2001), The Chinese Economy in Crisis: State Capacity and Tax Reform, Armonk, NY: M.E. Sharpe.

Weitzman, Martin L. and Chenggang Xu, "Chinese Township Village Enterprises as Vaguely Defined Cooperatives", Journal of Comparative Economics, 18(2): 121145, 1994.

Whiting, Susan H. (2000), Power and Wealth in Rural China: The Political Economy of Institutional Change. Cambridge: Cambridge University Press.

Williamson, Oliver E. (1985), The Economic Institutions of Capitalism: Firms, Markets, and Relational Contracting. New York: Free Press. 
Wong, Christine P. (1991), "Central-Local Relations in an Era of Fiscal Decline: The Paradox of Fiscal decentralization in Post-Mao China”, The China Quarterly, 128: 691-715.

Xu, Chenggang (2009), “The Institutional Foundations of China’s Reforms and Development”, mimeo, HKU, 2009.

Xu, Xianxiang, Wang Xianbin, and Shu Yuan (2007), "Local Officials and Economic Growth [Difang guanyuan yu jingji zengzhang]”, Economic Research Journal [Jingji yanjiu], 9: 18-32.

Yu, Jianrong (2005), “Land Issues Have Become the Focus in Peasants' Safeguarding of their Legal Rights-A Special Study of Contemporary Rural Society in China [Tudi wenti yi chengwei nongmin weiquan kangzheng de jiaodian]”, The World of Survey and Research [Diaoyan shijie], 3: 22-23.

Zhou, Feizhou (2006), “Ten Years of Fiscal Tax Revenue-Sharing: the Institution and Its Impact [Fenshuizhi shinian: zhidu jiqi yingxiang]”, Social Science in China [Zhongguo shehui kexue], 6: 100-105.

Zhou, Feizhou (2007), “The Road to Riches: Governments and Peasants in Land Development [Shengcai youdao: tudi kaifa zhong de zhengfu he nongmin]”, The Sociological Study [Shehuixue yanjiu], 1: 49-82.

Zhou, Qiren (2004), "Rural Property Rights and the Institution of Land-RequisitionCritical Choice in China's Rapid Urbanization [Nongdi chanquan yu zhengdi zhidu: jisu de zhongguo chengshihua mianlin de zhongda xuanze]", China Economic Quarterly [Jingjixue jikan], 4 (1): 193-210. 